\title{
Article \\ Study on Wear Resistance of Ti-6Al-4V Alloy Composite Coating Prepared by Laser Alloying
}

\author{
Quan Chen ${ }^{1}$, Jiajia Zhang ${ }^{1}$, Anguo Huang ${ }^{1, *}$ (1) and Pengyu Wei ${ }^{2}$ \\ 1 State Key Laboratory of Material Processing and Die \& Mould Technology, School of Materials Science and \\ Engineering, Huazhong University of Science and Technology, Wuhan 430074, China; \\ quan_c@hust.edu.cn (Q.C.); jiajia_z@hust.edu.cn (J.Z.) \\ 2 China Ship Scientific Research Center, Wuxi 214082, Jiangsu, China; structure@cssrc.com.cn \\ * Correspondence: huang-anguo@hust.edu.cn; Tel.: +027-875-436-76
}

Citation: Chen, Q.; Zhang, J.; Huang, A.; Wei, P. Study on Wear Resistance of Ti-6Al-4V Alloy Composite Coating Prepared by Laser Alloying. Appl. Sci. 2021, 11, 446. https://doi.org/10.3390/ app11010446

Received: 2 December 2020 Accepted: 31 December 2020 Published: 5 January 2021

Publisher's Note: MDPI stays neutral with regard to jurisdictional clai$\mathrm{ms}$ in published maps and institutional affiliations.

Copyright: (C) 2021 by the authors. Licensee MDPI, Basel, Switzerland. This article is an open access article distributed under the terms and conditions of the Creative Commons Attribution (CC BY) license (https:// creativecommons.org/licenses/by/ $4.0 /)$.

\begin{abstract}
Titanium alloy has extensive applications in numerous fields, such as in aerospace, shipbuilding, petrochemical, and bio-medical. However, under the condition of high temperature (above $700{ }^{\circ} \mathrm{C}$ ), it is difficult to meet the requirements of the performance of the turbine blades, piston rings, valves, etc. In this paper, the alloy powder is composed of Ni60A, TiN, Al, and $\mathrm{Si}$ in accordance with the proportion of 1:3:4:2 (mass ratio), and the composite coating, such as $\mathrm{TiN}, \mathrm{TiB} \mathrm{Ti}_{5} \mathrm{Si}_{3}$, and $\mathrm{Al}_{3} \mathrm{Ti}$ were synthesized on Ti-6Al-4V alloy by Yttrium Aluminium Garnet(YAG) laser. The friction and wear experiments were carried out on Ti-6Al-4V alloy and alloyed coatings at different loads ( $3 \mathrm{~N}$, $6 \mathrm{~N}, 9 \mathrm{~N})$, and different temperatures $\left(25^{\circ} \mathrm{C}, 350^{\circ} \mathrm{C}, 700^{\circ} \mathrm{C}\right)$. The impact of load and temperature on wear performance were analyzed by analyzing the friction traces. The results showed that the abrasion loss, wear width, and depth, wear volume, and wear ratio of the alloyed coatings were less than Ti-6Al-4V alloy, and the surface of furrow was shallow and the wear was less. However, under high temperature conditions, the alloy coating wears worse than Ti-6Al-4V alloy, and the high temperature wear resistance is not ideal.
\end{abstract}

Keywords: Ti-6Al-4V alloy; laser alloying; wear resistance

\section{Introduction}

With the development of technology and the requirements of deep space and deep-sea exploration, it is extremely important for equipment and structural parts to be stable, to serve under severe conditions, such as high stress, strong corrosion, and high temperature. The density of titanium is $4.506-4.516 \mathrm{~g} / \mathrm{cm}^{3}$, which is only about $55 \%$ of steel, and the strength of titanium alloy can reach 500-1400 $\mathrm{MPa}$, which meets the requirements of aerospace components [1-3]. In addition, titanium alloys have good performance at both high and low temperatures, and can work for long periods of time at $550{ }^{\circ} \mathrm{C}$ and $-253{ }^{\circ} \mathrm{C}$, accordingly, titanium alloy is called "space metal" [4,5]. Its application in aerospace engine turbine blades, piston rings, valves, marine heat exchangers, propellers, and other parts with high material performance requirements, is limited [6,7] due to its large friction coefficient [5], easy adhesion [8], poor wear resistance [9,10] (Figure 1a), and serious oxidation under high temperature conditions (Figure 1b). Therefore, improving the wear resistance of the titanium alloy is of great significance for broadening its application range in parts and components requiring high performance materials.

The surface properties of titanium alloy can be improved by laser surface alloying $[11,12]$. Laser surface alloying is a method of local modification of metal surface. It aims to change the composition, phase, and microstructure of the material surface, and then change the performance of the material surface, to meet the performance requirements of wear resistance, corrosion resistance, and oxidation resistance. Amal M. Nair et al. [13] synthesized TiCN coating in situ on Tie6Ale4V matrix by laser surface alloying, and the results showed that the dendritic structure of TiCN increased the hardness of the coating, 
and its corrosion resistance was significantly improved due to the alloying of Ti-6Al-4V matrix and TiCN. TianY S et al. [14] prepared $\mathrm{Ti}_{6} \mathrm{Ni}_{6} \mathrm{Si}_{7}, \mathrm{TiB}_{2}, \mathrm{TiNi}$, and $\mathrm{TiN}$ composite coatings by laser alloying on the surface of pure Ti using tin-B-Si-Ni mixed powder as raw material. The study showed that the hardness, wear resistance, and oxidation resistance of the surface of pure Ti were significantly improved.

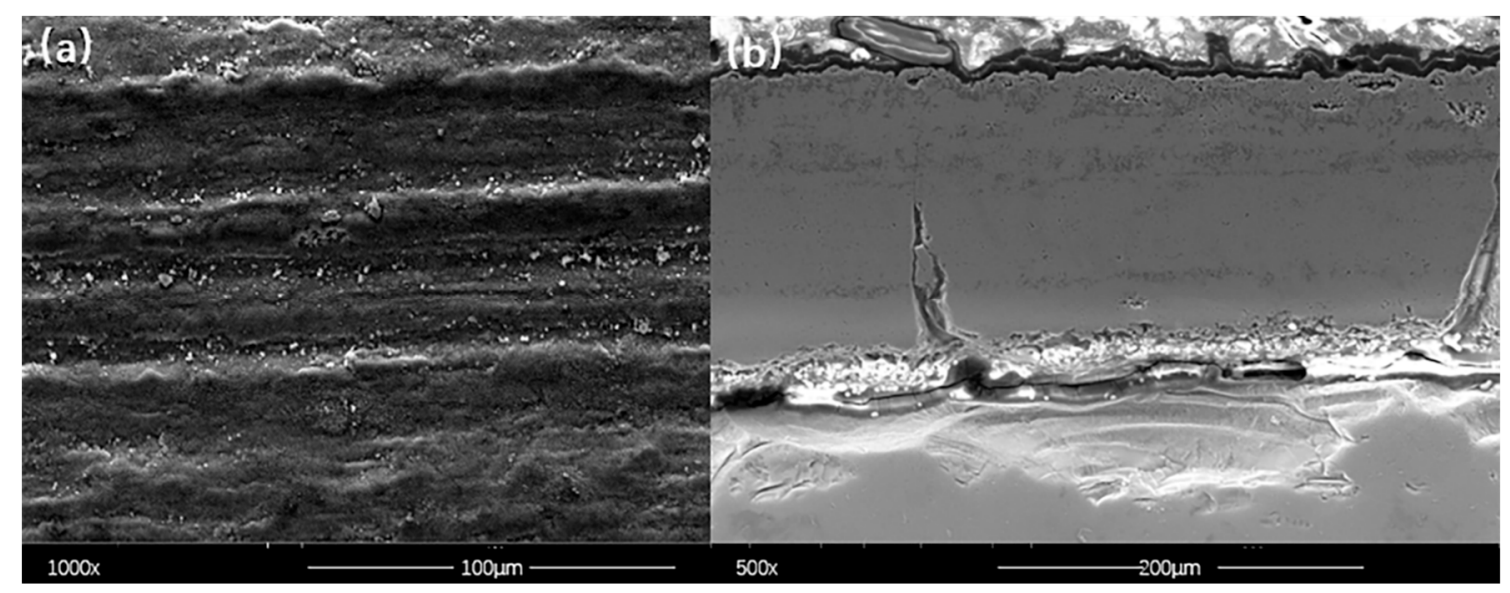

Figure 1. (a) Surface wear morphology of Ti-6Al-4V alloy; (b) cross section morphology of oxide layer.

Although the hard phase particles of $\mathrm{Ti}$ can enhance the surface strength of the matrix, it will also increase the wear on the matrix. Numerous studies have shown that the addition of silicon elements can improve the wear resistance and high temperature oxidation resistance. Fei Weng et al. [15] studied the microstructure and wear properties of coatings with different silicon contents on the surface of Ti-6Al-4V titanium alloy. The results showed that the microhardness of the coatings was increased to more than three times that of the substrate. Within a certain range, concerning the carbon content of silicon, the higher the wear resistance, the better. YS Tian et al. [16] used nitrogen and silicon powder laser alloying technology to prepare a composite strengthening coating containing $\mathrm{Si}_{3} \mathrm{~N}_{4}, \mathrm{Ti}_{5} \mathrm{Si}_{3}, \mathrm{Ti}_{2} \mathrm{~N}$, and other compounds on the surface of titanium alloy Ti-6Al-4V. The addition of Si not only improves the sliding of the coating the wear resistance, but also makes the coating have good oxidation resistance. Aluminum also plays an important role in improving the high temperature performance of titanium alloys. Ti-6Al-4V alloy has poor oxidation resistance due to its low aluminum content. Ti-6Al-4V alloy can only be used for the production of static and rotating parts of the fan low-pressure compressor with the temperature around $315^{\circ} \mathrm{C}$. Hongxi Liu et al. [17] prepared high temperature anti-oxidation $\mathrm{TiN} / \mathrm{Ti}_{3} \mathrm{Al}$ intermetallic compound composite coating on the surface of Ti6Al4V titanium alloy by in-situ laser cladding. The results showed that $\mathrm{TiN} / \mathrm{Ti}_{3} \mathrm{Al}$ intermetallic compound coating could effectively improve the high temperature oxidation resistance and mechanical properties of Ti-6Al-4V titanium alloy. It can be observed that aluminum and silicon elements play an important role in improving the surface properties of titanium alloys.

According to the survey, $\mathrm{TiB}$ [18], $\mathrm{TiN}$ [19], $\mathrm{TiC}$ [20], and $\mathrm{Ti}_{5} \mathrm{Si}_{3}$ [21] have high hardness, high strength, and high wear resistance, which are often used as reinforcing phases of composite materials. Moreover, $\mathrm{TiB}$ and $\mathrm{TiN}$ reinforcements have little influence on the toughness of Ti-6Al-4V alloy, which can effectively improve the wear resistance of metals without destroying their toughness. Ni60A contains 3.0 4.5\% element B. under the action of higher laser energy, Ni60A almost completely decomposes. Although the chemical bond between $\mathrm{Ti}$ and $\mathrm{N}$ is strong, tin is still partially decomposed, resulting in the existence of free Ti element, decomposed B, and added Si element to synthesize new phase TiB and $\mathrm{Ti}_{5} \mathrm{Si}_{3}$ in situ. The new phase $\mathrm{TiB}$ and $\mathrm{UN}$ decomposed tin constitute the reinforcement phase of the alloying coating, which improves the wear resistance of the titanium alloy. Therefore, $\mathrm{TiB}$, tin, $\mathrm{Al}_{3} \mathrm{Ti}$, and other composite phases can be obtained at the same time, 
which can improve the oxidation resistance and wear resistance of Ti-6Al-4V alloy at the same time. Therefore, Ni60A/TiN-Al-Si composite powder was planned to be used in this study.

The tribological properties of the composite coating and Ti-6Al-4V under different loads and temperatures were compared, and the mechanism of different wear results was analyzed. This has certain guiding significance for improving the wear resistance and high temperature resistance of the titanium alloy Ti-6Al-4V under harsh conditions, such as high temperature.

\section{Experiment}

The thickness of Ti-6Al-4V alloy is $5 \mathrm{~mm}$. The sample size is $120 \mathrm{~mm} \times 100 \mathrm{~mm} \times 5 \mathrm{~mm}$. Before laser alloying, the surface of the sample is polished with sandpaper to remove the surface oxide film, and then cleaned with acetone and ethanol, then dried for standby.

The composite powder in the experiment is $\mathrm{Ni60 \textrm {A }} / \mathrm{TiN} / \mathrm{Al} / \mathrm{Si}$, the purity of $\mathrm{Al}$ and Si powder is $99.5 \%$ and $99.9 \%$, correspondingly, the particle size is $200-400$ mesh and 325 mesh. Moreover, the chemical composition and particle size of Ni60A/TiN composite powder are shown in Table 1.

Table 1. Chemical composition and particle size of Ni60A/TiN.

\begin{tabular}{|c|c|c|c|c|c|c|c|}
\hline Powder & & Ch & nical Cor & osition (n & & & Size (Mesh) \\
\hline Ni60A & $\begin{array}{c}\mathrm{C} \\
0.5 \sim 1.1\end{array}$ & $\begin{array}{c}\mathrm{Cr} \\
15.0 \sim 20.0\end{array}$ & $\begin{array}{c}\text { B } \\
3.0 \sim 4.5\end{array}$ & $\begin{array}{c}\mathrm{Si} \\
3.5 \sim 5.5\end{array}$ & $\begin{array}{c}\mathrm{Fe} \\
\leq 5.0\end{array}$ & $\begin{array}{c}\mathrm{Ni} \\
\text { others }\end{array}$ & $150-400$ \\
\hline TiN & $\begin{array}{c}\mathrm{N} \\
\geq 21.5\end{array}$ & $\begin{array}{c}\mathrm{C} \\
<0.039\end{array}$ & $\begin{array}{c}\mathrm{O} \\
<0.033\end{array}$ & $\begin{array}{c}\mathrm{Fe} \\
<0.020\end{array}$ & $\begin{array}{c}\mathrm{Ti} \\
\text { others }\end{array}$ & & 300 \\
\hline
\end{tabular}

The test adopts the way of prefabricated powder. The preformed powder was uniformly covered on the surface of the material by air compressor. Then, under the action of high-energy laser beam, the prefabricated powder and Ti-6Al-4V alloy were melted and mixed at the same time, and then rapidly solidified, forming a good metallurgical combination. Moreover, $0.5 \%$ polyvinyl alcohol solution was used as binder and $20 \mathrm{~g}$ polyvinyl alcohol powder was weighed and placed in a beaker containing $380 \mathrm{~g}$ distilled water. Then the beaker was heated in a constant temperature water bath heating furnace, and continuously stirred until completely dissolved, forming a colorless and transparent viscous liquid, which was cooled to room temperature for standby.

The $500 \mathrm{~W}$ pulsed Yttrium Aluminium Garnet(YAG) laser was used in the experiment. The laser mode is pulse wave, the rated output power is $500 \mathrm{~W}$, the wavelength is $1.06 \mu \mathrm{m}$, the focal length $f=80 \mathrm{~mm}$, and the minimum focal spot diameter is $0.8 \mathrm{~mm}$. The parameters used in the experiment are: current $\mathrm{I}=200 \mathrm{~A}$, scanning speed $\mathrm{v}=5 \mathrm{~mm} / \mathrm{s}, 0$ defocus, argon protection.

The surface of the laser-alloyed samples was polished and $35.6 \mathrm{~mm} \times 25.4 \mathrm{~mm} \times 9 \mathrm{~mm}$ sample pieces were prepared by wire cutting machine. The friction and wear test was carried out by using multi-function friction and wear test equipment, as shown in Figure 2.

The $\mathrm{Si}_{3} \mathrm{~N}_{4}$ ceramic balls with a $6 \mathrm{~mm}$ diameter were used as the grinding materials. The load was set to $3 \mathrm{~N}, 6 \mathrm{~N}$, and $9 \mathrm{~N}$, respectively, and the reciprocating distance was $10 \mathrm{~mm}$. The friction and wear test lasted for $30 \mathrm{~min}$ at the speed of $16 \mathrm{~m} / \mathrm{min}$. The mass of the sample was measured before and after the test with a balance of precision of $0.1 \mathrm{mg}$ and the amount of friction loss was calculated. Moreover, the working temperature $\left(25^{\circ} \mathrm{C}\right.$, $350^{\circ} \mathrm{C}, 700^{\circ} \mathrm{C}$ ) was changed to detect the effect of temperature on the friction and wear properties of Ti-6Al-4V alloy and coating. It should be noted that $25^{\circ} \mathrm{C}$ is the temperature at room temperature, and $350{ }^{\circ} \mathrm{C}$ is the normal working temperature of Ti-6AL-4V, which is widely used in aerospace, medical, and other fields [22]. However, $700{ }^{\circ} \mathrm{C}$ is not the normal working temperature of Ti- $6 \mathrm{Al}-4 \mathrm{~V}$, which is obviously higher than the maximum service temperature of Ti-6Al-4V alloy, but lower than its $\beta$-transformation temperature (about 
$\left.995^{\circ} \mathrm{C}\right)$. At the same time, the temperature is higher than the eutectic temperature of $\mathrm{Al} \mathrm{Si}$ alloy (about $577^{\circ} \mathrm{C}$ ) and the melting point of pure $\mathrm{Al}\left(\right.$ about $660^{\circ} \mathrm{C}$ ) [23].

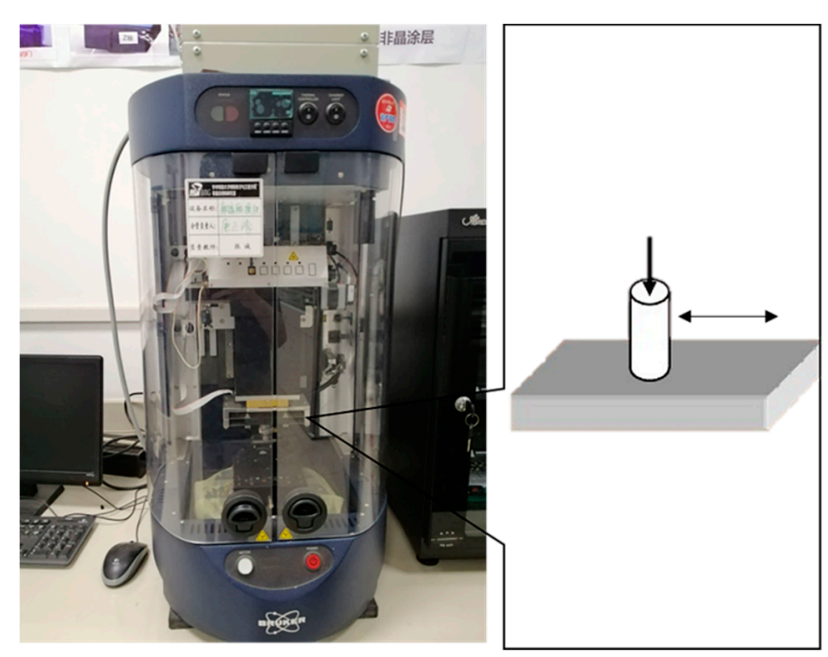

Figure 2. Multi-functional friction and wear testing machine. (UMT-TL).

The samples after laser alloying were cut into $10 \mathrm{~mm} \times 5 \mathrm{~mm} \times 5 \mathrm{~mm}$ blocks by wire cutting, and then the samples were inlaid along the direction perpendicular to the laser scanning. The samples were then ground and polished. Finally, the samples were corroded with $\mathrm{HF}: \mathrm{HCl}: \mathrm{HNO}_{3}: \mathrm{H}_{2} \mathrm{O}=1: 1.5: 2.5: 95$ corrosive solution. After 40 s of corrosion, the samples were cleaned with absolute ethanol and dried.

Microstructure and composition analysis the metallographic structure of the sample after corrosion was observed by Quanta400 scanning electron microscope (FEI American), and the composition of different micro areas of laser alloying coating was analyzed by Energy Dispersive Spectrometer (EDS). X-ray diffractometer (D/max-2500) was used to analyze the phase of laser alloying coating, oxide layer and wear surface. HX-1000 microhardness tester was used. The applied load was $1 \mathrm{n}$ and the pressure was maintained for $15 \mathrm{~s}$. The microhardness of the alloyed coating was detected from the top to the bottom along the cross section of the coating. The average value was measured three times on the same horizontal line.

\section{Results and Discussion}

\subsection{Phase Composition and Microhardness Analysis of Alloying Coating}

The phase structure of the alloying coating was analyzed by D/Max-2500 X-ray diffractometer from Japan. Figure 3 shows the X-ray diffraction pattern of the alloying coating.

It can be seen from Figure 3 that the coating contains $\mathrm{Ti}, \mathrm{SiC}, \mathrm{TiN}, \mathrm{TiB}, \mathrm{Al}_{3} \mathrm{Ti}_{1} \mathrm{Ti}_{5} \mathrm{Si}_{3}$, and other phase structure. $\mathrm{TiN}, \mathrm{TiB}, \mathrm{Ti}_{5} \mathrm{Si}_{3}$ have high hardness, strength, and wear resistance, which can improve the hardness and wear resistance of the coating. Under high temperature conditions, $\mathrm{Al} 3 \mathrm{Ti}$ is easily oxidized to form uniform and dense $\mathrm{Al}_{2} \mathrm{O}_{3}$, which can improve the oxidation resistance of the titanium alloy surface layer. Hardness test is to characterize the force energy of wear resistance by friction with loading abrasive tools, so hardness can be used as the main parameter of wear resistance of a material. Figure 4 shows the microhardness distribution of the alloy coating. It shows that the microhardness of the alloyed coating is significantly higher than that of the titanium alloy. The average microhardness of the alloyed coating is $685 \mathrm{HV}_{0.5}$, and the microhardness of Ti-6Al-4V alloy is $343 \mathrm{HV}_{0.5}$, which is about twice of that. Because the alloy coating contains high hardness $\mathrm{Ti}_{5} \mathrm{Si}_{3}$ and other materials, the specific strength and specific stiffness of Ti Al compound are higher. The microhardness in the dilution zone is significantly lower than that in the alloying zone. Due to the dilution effect of the substrate on the coating, the microhardness of the coating near the substrate increases slightly. In the alloyed coating, 
the hardness far away from the surface is slightly higher, which is caused by the uneven distribution of hard particles in the coating.

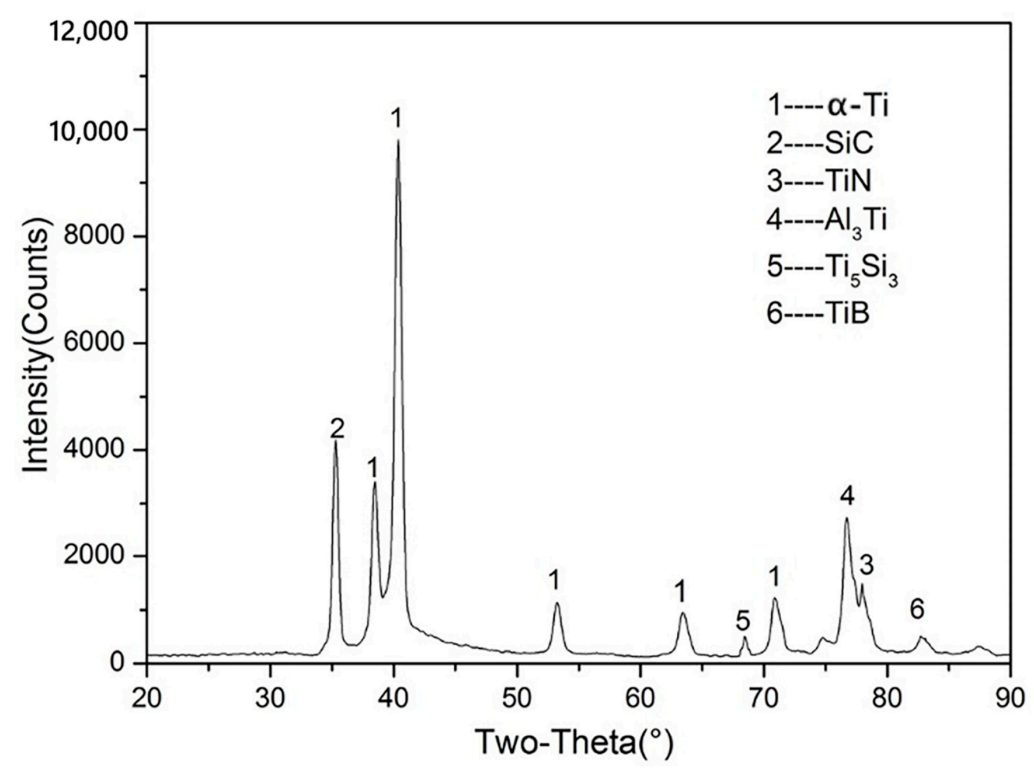

Figure 3. X-ray diffraction pattern of alloying coating.

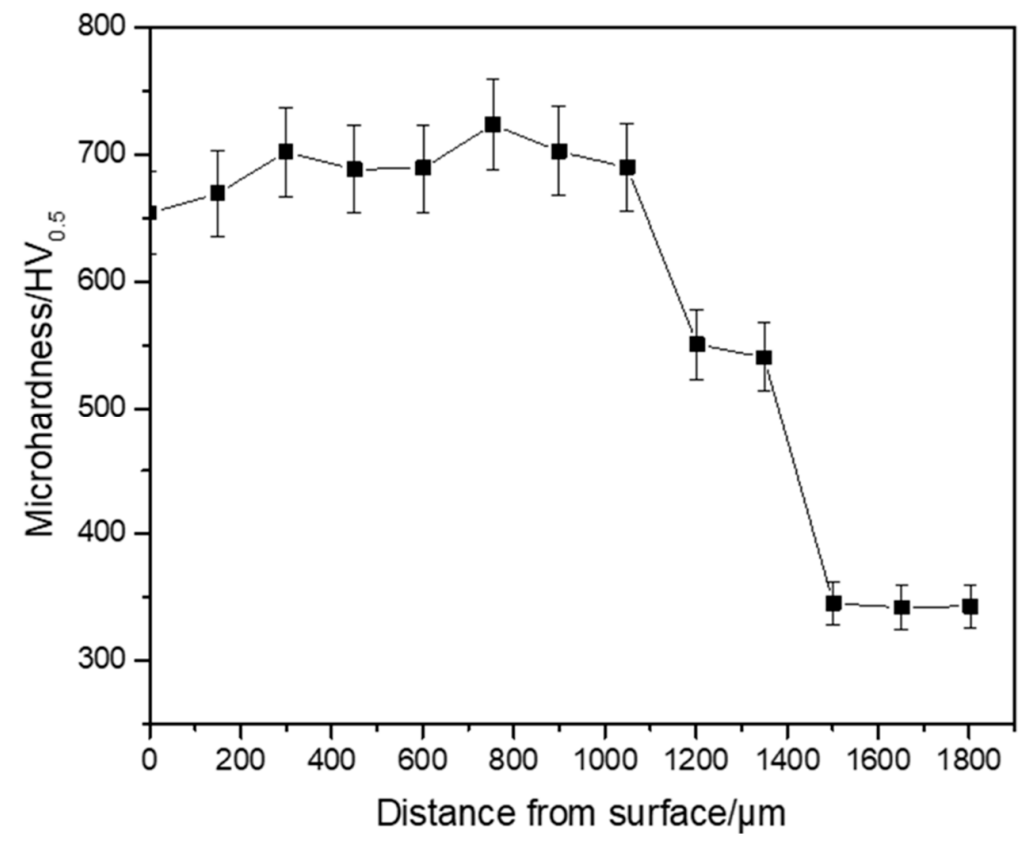

Figure 4. Microhardness distribution of alloying coating.

From the energy spectrum in Figure 5, it can be seen that the middle part of the coating mainly contains $\mathrm{Ti}, \mathrm{N}, \mathrm{Si}$, and a small amount of $\mathrm{B}$. Moreover, the X-ray diffraction pattern in Figure 3 shows that the coating mainly contains TiN and a small amount of TiB, $\mathrm{Ti}_{5} \mathrm{Si}_{3}$. In the composite of Ni60A, B elements account for 3.0\% to $4.5 \%$, so Ni60A is almost completely decomposed under the action of higher laser energy [24,25]. Although the chemical bond between Ti and $\mathrm{N}$ is strong, TiN is partially decomposed. Free Ti element and $\mathrm{B}, \mathrm{Si}$ elements can be in situ synthesis of new phase $\mathrm{TiB}$ and $\mathrm{Ti}_{5} \mathrm{Si}_{3}$. The new phase $\mathrm{TiB}, \mathrm{Ti}_{5} \mathrm{Si}_{3}$ and $\mathrm{TiN}$ are both hard particles, which can effectively increase the hardness of the coating. 


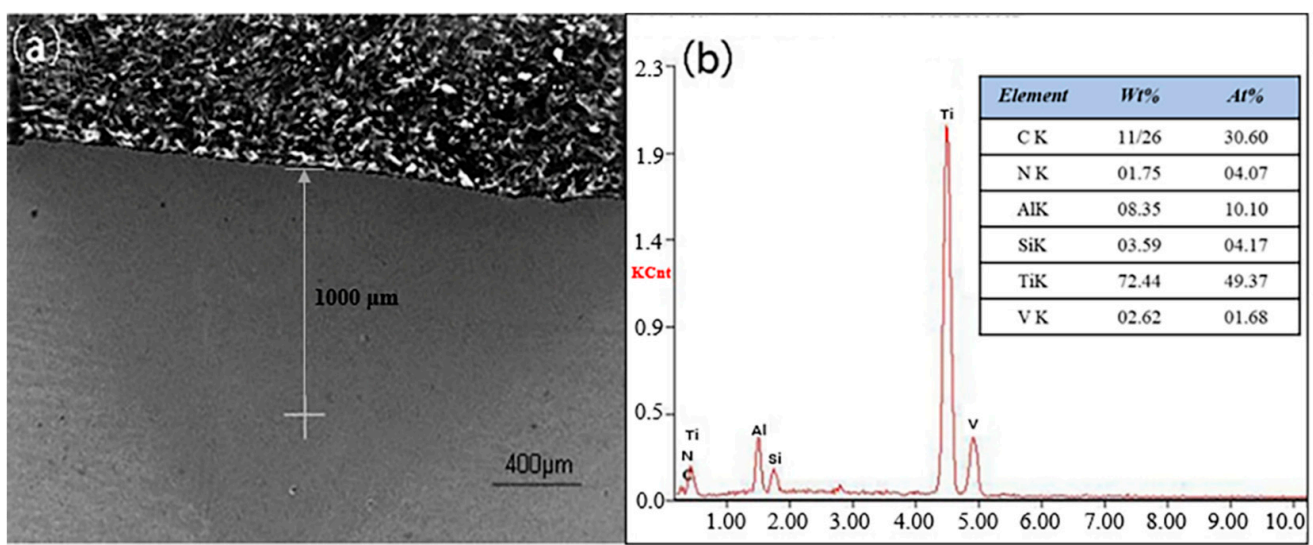

Figure 5. Cross-sectional morphology and point energy spectrum analysis of the wear surface: (a) coating cross-section morphology; (b) point spectrum analysis.

\subsection{Impact of Load Variation on Friction and Wear Properties}

\subsubsection{Effect on Coefficient Friction}

At room temperature, the friction coefficient of Ti-6Al-4V alloy and alloying coating varied with the wear time in the friction and wear test of different loads, as shown in Figure 6. When the load was $3 \mathrm{~N}$, the friction coefficient of Ti-6Al-4V alloy increased with the wear time in the first $15 \mathrm{~min}$, then stabilized after $15 \mathrm{~min}$ and the friction coefficient was kept in the range of $0.47-0.53$. When the load was $6 \mathrm{~N}$, the pre-grinding period was reduced to $10 \mathrm{~min}$, then stabilized, and the friction coefficient was kept in the range of $0.40 \sim 0.47$. When the load increased to $9 \mathrm{~N}$, there was no pre-grinding period, it was directly into the stable period. The friction coefficient decreased and maintained in the range of $0.39-0.44$ eventually, indicating that it was the most stable.

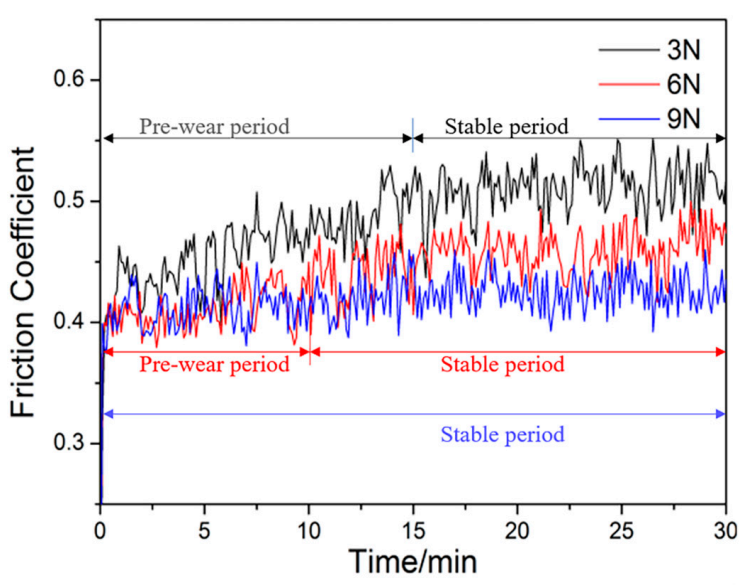

(a)

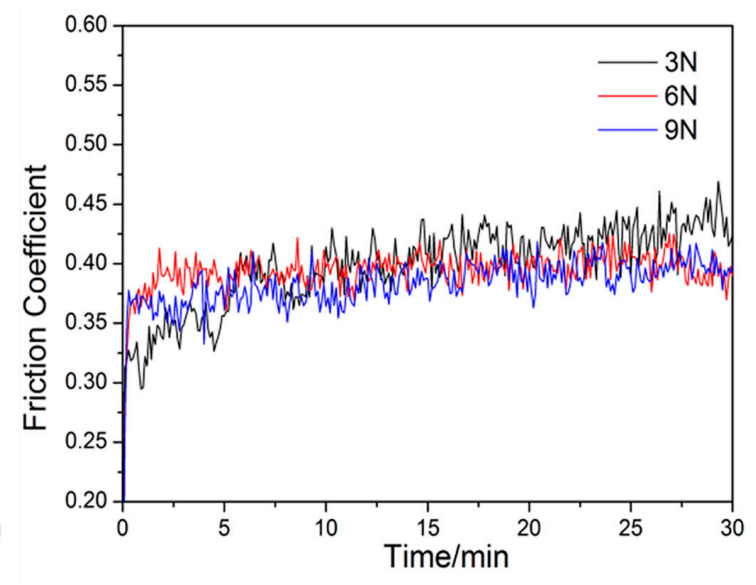

(b)

Figure 6. Variation curve of friction coefficient of Ti-6Al-4V alloy and alloying coating under different load: (a) Ti-6Al-4V alloy; (b) alloying coating.

Ti-6Al-4V alloy was subjected to normal stress and tangential force during the wear process with $\mathrm{Si}_{3} \mathrm{~N}_{4}$ ceramic balls, and friction first occurs on the bumps that contact each other. When the load was $3 \mathrm{~N}$, the normal stress applied to the surface of Ti-6Al-4V alloy was small, the squeezing force of the bumps on the surface of $\mathrm{Si}_{3} \mathrm{~N}_{4}$ and Ti-6Al-4V alloy was also small, the bumps were difficult to be smoothed in a short time, and the surface of Ti-6Al-4V alloy remained uneven rough state, so the coefficient of frictionin was large. When the load was increased, the size and number of contact points of the $\mathrm{Si}_{3} \mathrm{~N}_{4}$ ceramic ball and the Ti-6Al-4V alloy also increased, and the bumps on the surface of the Ti-6Al-4V 
alloy underwent plastic deformation due to the large squeezing force, and even broke and flake to formed abrasive debris. The abrasive particles began to wear, and the shear stress decreased accordingly. At this time, although the contact area of the friction and wear surface increased, when the metal was in the elastoplastic state, the effective contact area was proportional to $2 / 3$ of the applied load, so the friction coefficient decreased.

From Figure $6 \mathrm{~b}$, it can be seen that, when the load was $3 \mathrm{~N}$, the wear of the alloyed coating also had a pre-grinding period, but the time was shorter than that of the Ti-6Al-4V alloy, about $6 \mathrm{~min}$, and the fluctuation range of the friction coefficient was smaller, from 0.39 to 0.42 . When the load increased to $6 \mathrm{~N}, 9 \mathrm{~N}$, the pre-grinding period was no longer obvious, entering the wear stabilization period faster, and the floating range of the friction coefficient became smaller, and the stability was better. The friction coefficient of the alloyed coating under different loads was lower than that of the Ti-6Al-4V alloy. Firstly, the hardness of the alloyed coating was much higher than that of the Ti-6Al-4V alloy, thereby reducing the tangential resistance between the $\mathrm{Si}_{3} \mathrm{~N}_{4}$ ceramic ball and the alloyed coating. Secondly, the hardness of the titanium alloy was much smaller than that of the $\mathrm{Si}_{3} \mathrm{~N}_{4}$ ceramic ball. During the contact and wear between the two, the Ti-6Al-4V alloy was prone to plastic deformation and adhesion, and the intermetallic compound of the alloyed coating can effectively reduce the adhesion resistance [26].

\subsubsection{Effect on Abrasion Loss}

Table 2 shows the comparison of the abrasion loss of Ti-6Al-4V alloy and alloying coating under different loads. It is apparent from the table that the loss of the alloying coating under different loads is less than that of the Ti-6Al-4V alloy. With the increase of the load, the abrasion loss of the material also increases, which coincides with the Archard wear theorem. Because the larger the load applied in the same wear time, the greater the positive pressure and shear force on the surface of the material, which make the plastic deformation and local peeling found on wear surface.

Table 2. The abrasion loss of Ti-6Al-4V alloy and alloying coating under different load.

\begin{tabular}{cccc}
\hline Load & $\mathbf{3 ~ N}$ & $\mathbf{6 ~ N}$ & $\mathbf{9 ~ N}$ \\
\hline Ti-6Al-4V alloy & $0.5 \mathrm{mg}$ & $1.1 \mathrm{mg}$ & $2.1 \mathrm{mg}$ \\
Alloying coating & $0.3 \mathrm{mg}$ & $0.7 \mathrm{mg}$ & $1.4 \mathrm{mg}$ \\
\hline
\end{tabular}

\subsubsection{Effect on Wear Volume and Specific Wear Ratio}

Three-dimensional super-depth microscope was used to observe the wear surface of the sample. As shown in Figure 7, the wear depth (h) and the width (b) of the sample can be obtained from Figure $7 \mathrm{~b}$.

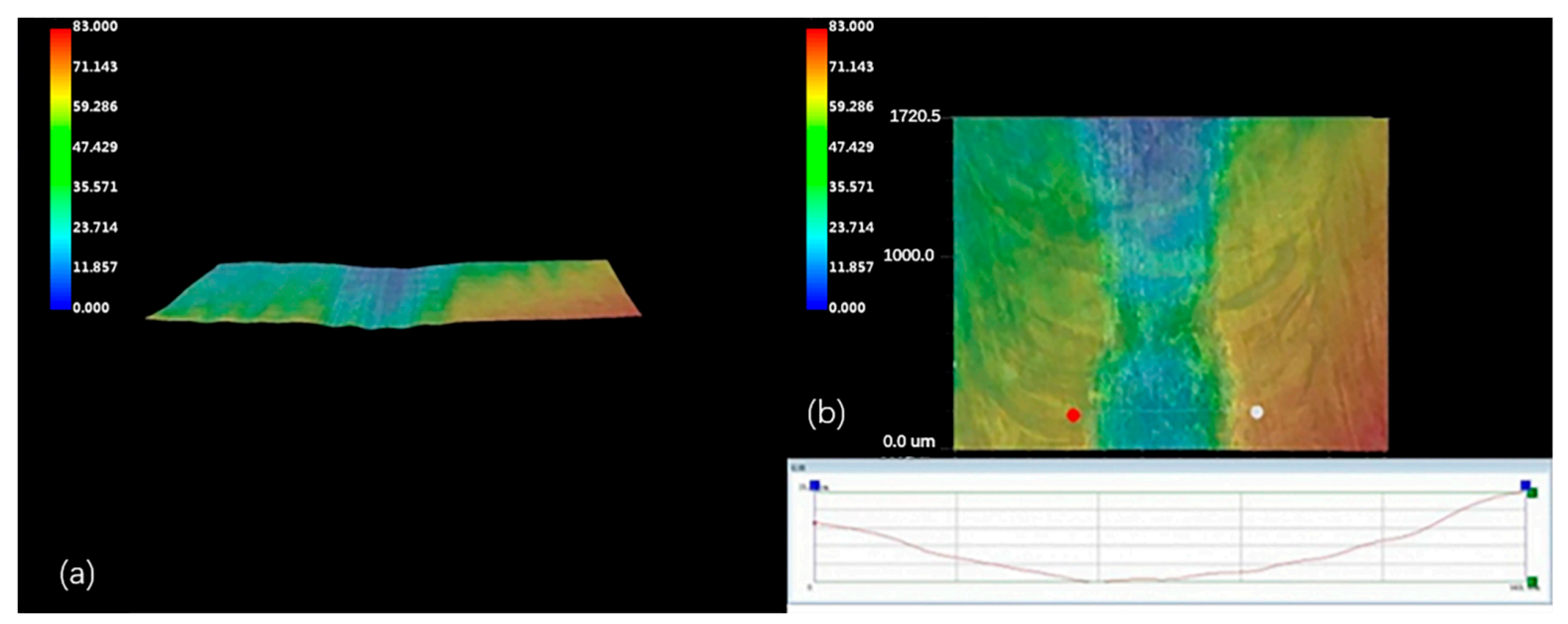

Figure 7. Three-dimensional morphology of wear surface: (a) front view; (b) vertical view. 
The wear volume $V_{W}$ and the specific wear rate $K$ can be calculated from the Equations (1) and (2) [27].

$$
V_{W}=\frac{\mathrm{hl}}{6 \mathrm{~b}}\left(3 \mathrm{~h}^{2}+4 \mathrm{~b}^{2}\right)
$$

where $V_{W}$ is wear volume, the unit is $\mathrm{mm}^{3}, \mathrm{~h}, \mathrm{~b}$, and $\mathrm{l}$ are the wear depth, width, and length, the unit is $\mathrm{mm}$.

$$
K=\frac{V_{W}}{P S}
$$

where $K$ is the specific wear rate, the unit is $\mathrm{mm}^{3} \cdot \mathrm{N}^{-1} \cdot \mathrm{m}^{-1}, V_{W}$ is wear volume, the unit is $\mathrm{mm}^{3}, P$ is the normal load, the unit is $\mathrm{N}$, and $S$ is the sliding distance, the unit is $\mathrm{m}$.

Tables 3 and 4 show the wear volume and specific wear rate of Ti-6Al-4V alloy and alloying coating under different load. From Table 3, the wear width, depth, and volume of Ti-6Al-4V alloy increase with the increase of the load. From Table 4 that the wear volume of the alloying coating also increases with the increase of the load, but its increasing rate is lower than the Ti-6Al-4V alloy. The specific wear rate is about $50 \%$ of titanium alloy, which is obviously lower than that of Ti-6Al-4V alloy, indicating that alloying coating has good wear resistance.

Table 3. The wear width, depth, volume, and specific wear rate of Ti-6Al-4V alloy under different load.

\begin{tabular}{ccccc}
\hline Load (N) & Wear Width b $\mathbf{( m m )}$ & Wear Depth h $\mathbf{( m m )}$ & Wear Volume $V_{W}\left(\mathbf{m m}^{\mathbf{3}}\right)$ & $\begin{array}{c}\text { Specific Wear Rate } \\
\left(\mathbf{m m}^{3} \cdot \mathbf{N}^{-1} \cdot \mathbf{m}^{-1}\right)\end{array}$ \\
\hline 3 & 0.978 & $11.796 \times 10^{-3}$ & 0.1154 & $0.080 \times 10^{-3}$ \\
6 & 1.100 & $23.169 \times 10^{-3}$ & 0.2549 & $0.089 \times 10^{-3}$ \\
9 & 1.278 & $37.386 \times 10^{-3}$ & 0.4800 & $0.111 \times 10^{-3}$ \\
\hline
\end{tabular}

Table 4. The wear width, depth, volume, and specific wear rate of alloying coating under different load.

\begin{tabular}{ccccc}
\hline Load (N) & Wear Width b $\mathbf{( m m )}$ & Wear Depth h $\mathbf{( m m )}$ & Wear Volume $V_{W}\left(\mathbf{m m}^{\mathbf{3}}\right)$ & $\begin{array}{c}\text { Specific Wear Rate } \\
\left(\mathbf{m m}^{3} \cdot \mathbf{N}^{-1} \cdot \mathbf{m}^{-1}\right)\end{array}$ \\
\hline 3 & 0.833 & $8.240 \times 10^{-3}$ & 0.0686 & $0.048 \times 10^{-3}$ \\
6 & 0.878 & $15.961 \times 10^{-3}$ & 0.1401 & $0.049 \times 10^{-3}$ \\
9 & 1.144 & $25.376 \times 10^{-3}$ & 0.2903 & $0.067 \times 10^{-3}$ \\
\hline
\end{tabular}

\subsubsection{Effect on Wear Morphology}

Figure $8 \mathrm{a}, \mathrm{c}, \mathrm{e}$ show the wear surface morphology of Ti-6Al-4V alloy under $3 \mathrm{~N}, 6 \mathrm{~N}$ and $9 \mathrm{~N}$ load, respectively, Figure $8 \mathrm{~b}, \mathrm{~d}, \mathrm{f}$ are their partial magnification. From Figure $8 \mathrm{a}, \mathrm{b}$ that the wear marks showed obvious furrow morphology and plastic deformation. In Figure $8 \mathrm{c}, \mathrm{d}$, there was not only a clear furrow, but also some wear debris. As the load increased, the normal stress and shear force applied on the surface of the Ti-6Al-4V alloy increased, the Ti-6Al-4V titanium alloy underwent significant plastic deformation, and adhered to the $\mathrm{Si}_{3} \mathrm{~N}_{4}$ ceramic ball, partially plastically deformed soft metal and protrusions. The hard spots were separated from the Ti-6Al-4V titanium alloy under the action of shear force, which caused abrasive wear during friction during shedding.

A deep grinding furrow on the wear surface as shown in Figure 8e,f, and there was some metal stripping near the furrow edge. Figure 9 shows the wear cross-section trajectory curve of Ti-6Al-4V alloy when the load was $9 \mathrm{~N}$. It was obvious that the wear depth was larger in the middle part, while it was shallow at the edge, because when the load was $9 \mathrm{~N}$, the force on the surface of Ti-6Al-4V alloy was larger. According to the wear cross-section trajectory curve of Ti-6Al-4V alloy, the wear depth and width increase with the increasing load, and the depth increase was larger. 


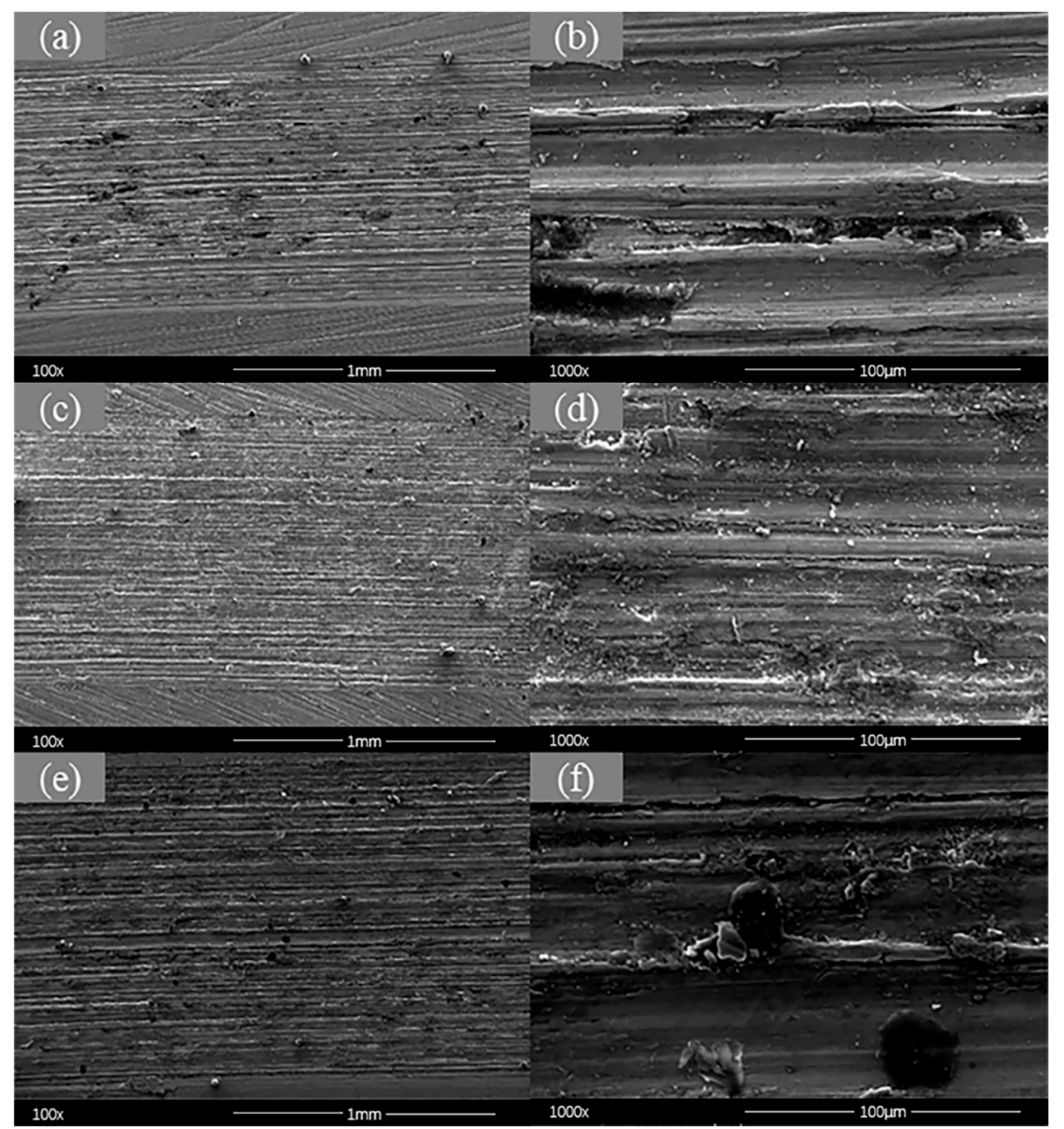

Figure 8. Wear morphology of Ti-6Al-4V alloy under different load. $(\mathbf{a}, \mathbf{b}): 3 \mathrm{~N} ;(\mathbf{c}, \mathbf{d}): 6 \mathrm{~N} ;(\mathbf{e}, \mathbf{f}): 9 \mathrm{~N}$.

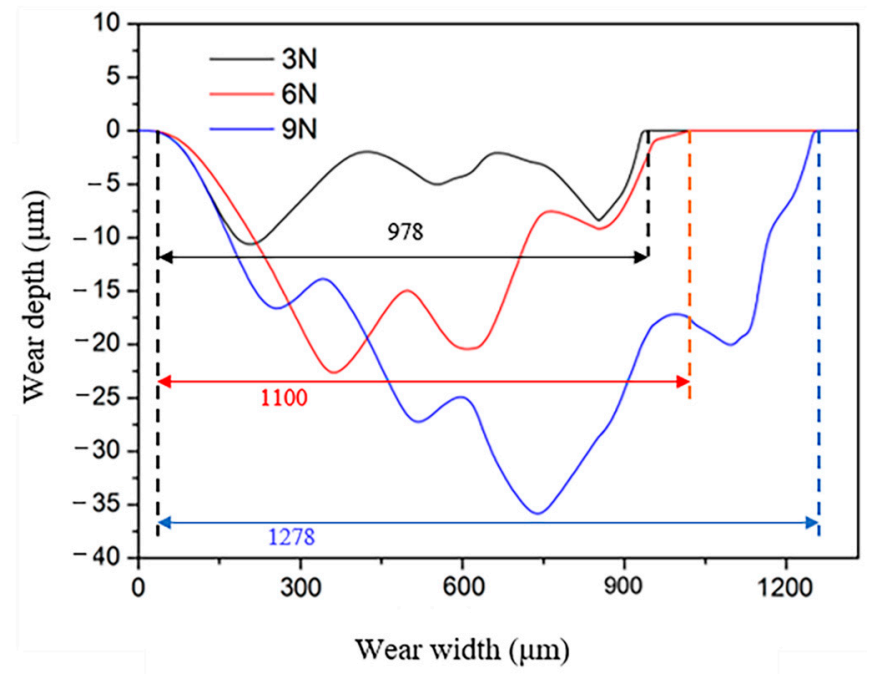

Figure 9. Wear cross-section trajectory curve of Ti-6Al-4V alloy under different load.

Figure 10 shows the wear surface morphology of alloying coating under $3 \mathrm{~N}, 6 \mathrm{~N}$, and $9 \mathrm{~N}$ load at room temperature. From Figure 10a,b, it can be seen that when the load was $3 \mathrm{~N}$, 
the wear surface was smooth, the furrow was shallow, the degree of plastic deformation was small, and the metal at the furrow edge was not inclined from breaking away from the friction surface. As shown in Figure 10c,d, when the load increased to $6 \mathrm{~N}$, the furrow was deepened, there was a slight plastic deformation on the wear surface, and a small amount of metal broke away from the surface, resulting in increased grinding particles on the wear surface. As shown in Figure 10e,f, the depth of the furrow increased with the increasing load, debris on the wear surface also increased. When compared with the wear morphology of Ti-6Al-4V alloy under corresponding loads, it was obvious that the wear resistance ability of alloying coating was better than that of Ti6Al4V alloy at room temperature, because $\mathrm{TiN}, \mathrm{TiB}, \mathrm{Ti}_{5} \mathrm{Si}_{3}$, and other hard particles existed on the surface of the alloying coating, in the same condition, serious plastic deformation was relatively difficult to form and the metal of the coating was not easy to break away from the surface. Consequently, the amount of debris was less and the wear was not serious.

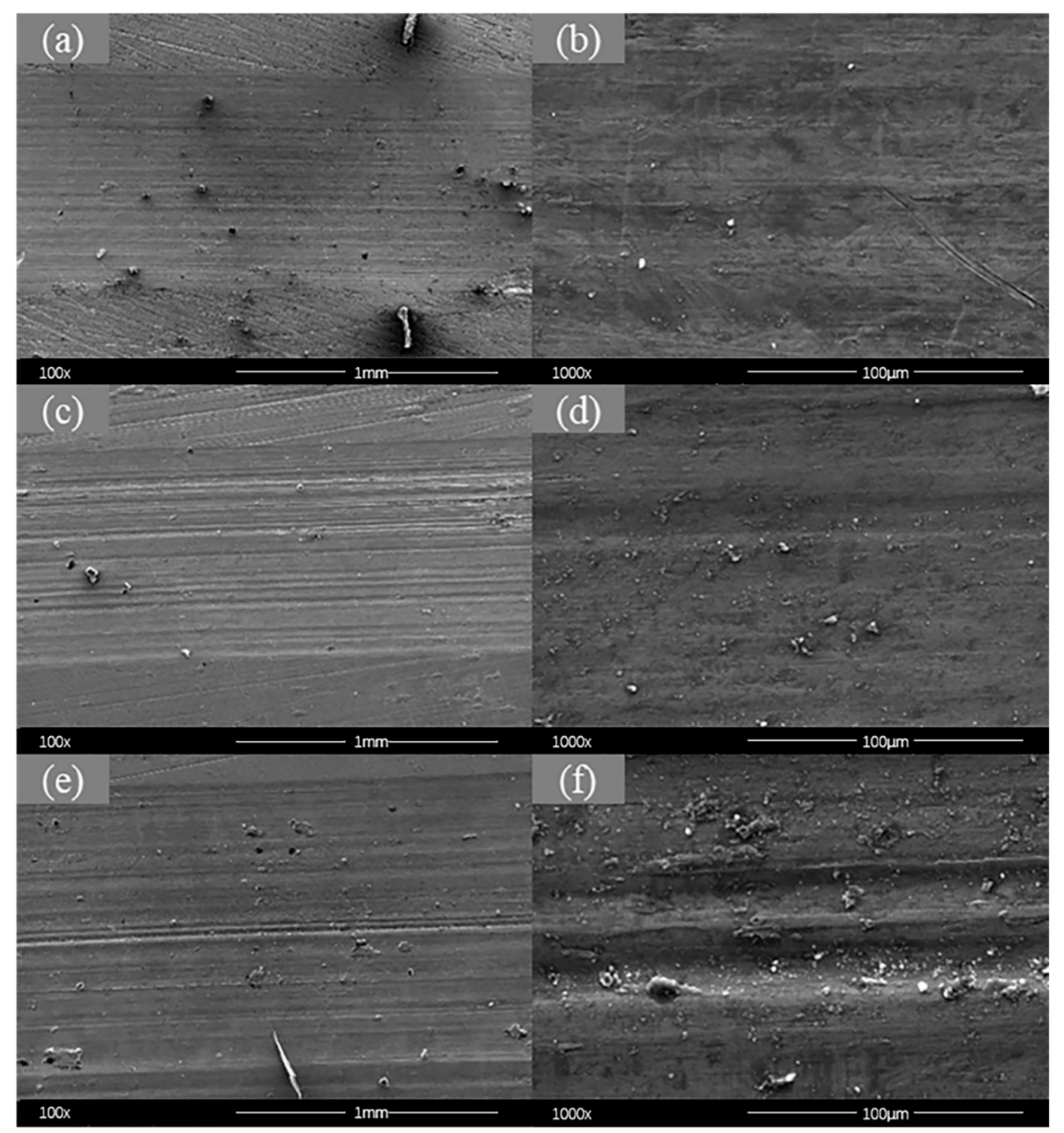

Figure 10. Wear morphology of alloying coating under different load. $(\mathbf{a}, \mathbf{b}): 3 \mathrm{~N} ;(\mathbf{c}, \mathbf{d}): 6 \mathrm{~N} ;(\mathbf{e}, \mathbf{f}): 9 \mathrm{~N}$.

Figure 11 shows the wear cross-section trajectory curve of the alloying coating under different loads. It can be found that the wear depth and width of the alloying coating increased with the increasing load. As the load increases, the friction coefficient of the Ti-6Al-4V alloy surface decreases during the friction and wear process, the amount of wear and the specific wear rate increases, the depth of the furrow of the wear scar surface 
increases, and the amount of wear debris increases, indicating that, with the load, the increase of titanium alloy surface wear is serious. With the increase of the load, the friction coefficient of the laser alloy coating remains in the range of $0.39 \sim 0.42$, but the amount of wear and wear rate increase, and the depth of the furrow of the wear scar surface increases. The increase in the amount of wear debris indicates that the wear of the alloyed coating increases as the load increases. Comparing Ti-6Al-4V alloy and alloyed coating, it can be seen that the wear resistance of laser-alloyed coating is higher than that of Ti-6Al-4V alloy at room temperature.

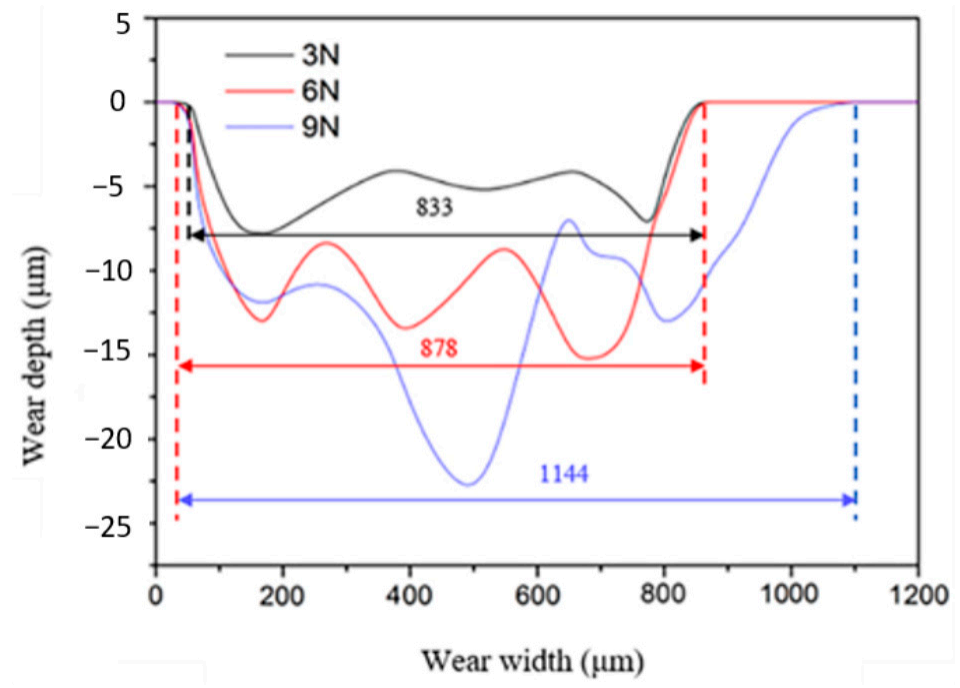

Figure 11. Wear cross-section trajectory curve of alloying coating under different load.

\subsection{Impact of Temperature Variation on Friction and Wear Properties}

This section discusses the effect of temperature on the friction and wear properties of Ti-6Al-4V alloy and alloyed coating. The test parameters are as follows: using the $\mathrm{Si}_{3} \mathrm{~N}_{4}$ ceramic ball with a diameter of $6.3 \mathrm{~mm}$ as the grinding material, apply $6 \mathrm{~N}$ load, sliding speed of $16 \mathrm{~m} / \mathrm{min}$, and wear for $30 \mathrm{~min}$.

\subsubsection{Effect on Friction Coefficient}

Figure 12 shows the friction coefficient of Ti6Al4V alloy and alloying coating at different temperatures. In Figure 12a, the friction coefficient of Ti-6Al-4V alloy fluctuated in the range of $0.41-0.46$ in the stable stage at room temperature. When the temperature rose to $350{ }^{\circ} \mathrm{C}$, the friction coefficient of Ti-6Al-4V alloy decreased to $0.40-0.42$, and at $700{ }^{\circ} \mathrm{C}$, the friction coefficient of Ti-6Al-4V alloy was less than 0.40 .
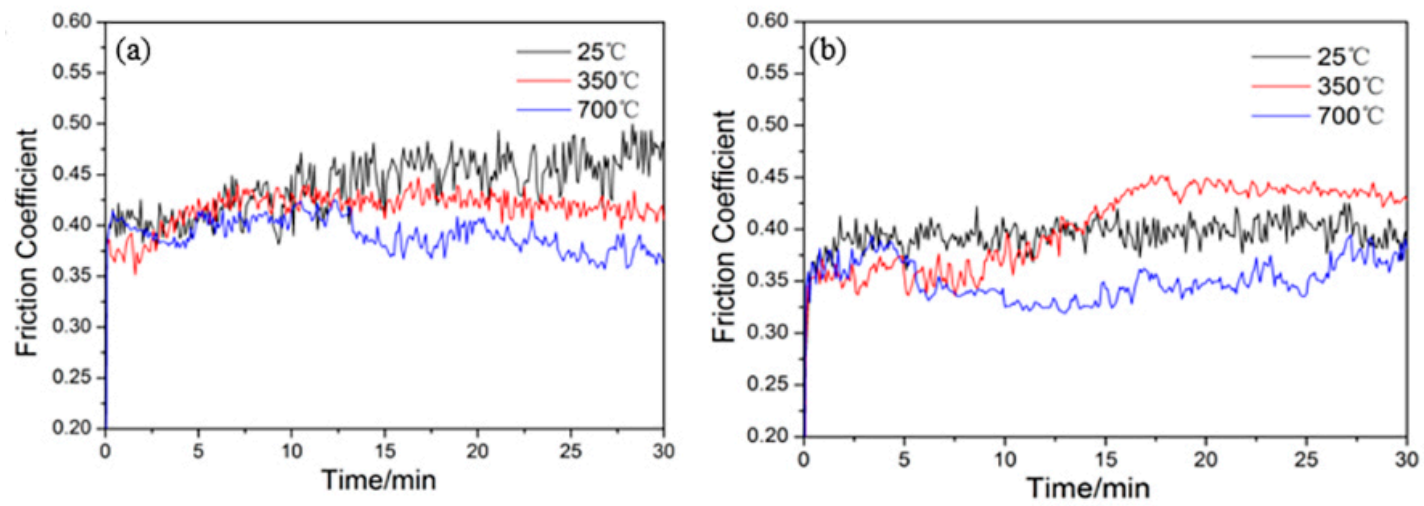

Figure 12. Variation curve of friction coefficient of Ti-6Al-4V alloy and alloying coating at different temperature. (a) Ti-6Al-4V alloy; (b) alloying coating. 
Figure 12 shows that, as the temperature increases, the friction coefficient of Ti6Al4V alloy during friction and wear gradually decreases, because, as the temperature increases, the viscosity of the metal increases, the material softens, and the friction resistance becomes smaller, while the surface of the Ti6Al4V alloy is oxidized, and the oxide film is separated from the wear debris formed under the load, and accumulates on the grinding surface, entering the pits or furrows of the wear scar, acting as a lubricant, and reducing the friction coefficient.

When the temperature rose to $700{ }^{\circ} \mathrm{C}$, the friction coefficient of Ti6Al4V titanium alloy fluctuated greatly. The friction coefficient at the initial stage is large and the stability is good. As the wear time increases, the friction coefficient decreases, but after 13 min, the friction coefficient has a non-monotonic changing trend with time. Because the Ti6Al4V titanium alloy is not fully oxidized at the initial stage, similar to the wear mechanism at $350{ }^{\circ} \mathrm{C}$, but with the extension of the wear time, the Ti6Al4V titanium alloy is severely oxidized. When friction wear is caused on the grinding ball and the oxide layer, the friction coefficient increases, and then the oxide film will squeeze and deform under the load, acting as a lubricant, and the friction coefficient will be reduced, so the fluctuation is larger.

As shown in Figure 12b, at room temperature, the coefficient of friction of the coating was relatively stable, maintaining a range of 0.37 to 0.40 . When the temperature rose to $350{ }^{\circ} \mathrm{C}$, the friction coefficient of the coating was lower than the value at room temperature in the initial stage of wear. After the wear lasted for $10 \mathrm{~min}$, the friction coefficient began to increase beyond the value at room temperature. Because with the prolongation of wear, the $\mathrm{Al}_{3} \mathrm{Ti}$ and $\mathrm{Ti}_{5} \mathrm{Si}_{3}$ phases on the surface of the coating are oxidized to form oxide films of $\mathrm{Al}_{2} \mathrm{O}_{3}, \mathrm{SiO}_{2}, \mathrm{TiO}_{2}$. The oxide film is very thin and is mainly $\mathrm{Al}_{2} \mathrm{O}_{3} . \mathrm{Al}_{2} \mathrm{O}_{3}$ is a brittle oxide, which breaks and flakes under the pressure of the grinding ball to form abrasive debris, and then contacts the grinding ball with the alloyed coating. Due to the interaction between the hard phase of the grinding ball and the coating surface and the abrasive debris, the friction coefficient becomes larger, which is manifested by the wear mechanism of abrasive wear, oxidative wear, and adhesive wear.

\subsubsection{Effect on Abrasion Loss}

Table 5 shows the abrasion loss of Ti-6Al-4V alloy and alloying coating at different temperatures. It is clear from Table 5 that the abrasion loss of Ti-6Al-4V alloy and alloying coating decreases with the increasing temperature, but the decreasing degree of Ti-6Al$4 \mathrm{~V}$ alloy is larger. At $700{ }^{\circ} \mathrm{C}$, the amount of abrasion loss of Ti-6Al-4V alloy is less than alloying coating. It can be seen that the wear resistance ability of alloying coating at room temperature is better than Ti-6Al-4V alloy, but worse at high temperatures.

Table 5. The abrasion loss of Ti-6Al-4V alloy and alloying coating at different temperatures.

\begin{tabular}{cccc}
\hline Temperature $\left({ }^{\circ} \mathbf{C}\right)$ & $\mathbf{2 5}$ & $\mathbf{3 5 0}$ & $\mathbf{7 0 0}$ \\
\hline Ti-6Al-4V alloy $(\mathrm{mg})$ & 1.1 & 0.7 & 0.2 \\
Alloying coating $(\mathrm{mg})$ & 0.7 & 0.5 & 0.3 \\
\hline
\end{tabular}

\subsubsection{Effect on Wear Volume and Specific Wear Ratio}

Tables 6 and 7 show the wear volume and specific wear rate of Ti-6Al-4V alloy and alloying coating at different temperatures. As shown in Table 6, with the increased in temperature, the wear width narrowed, the wear depth decreased and the wear volume reduced. As shown in Table 7, the wear volume of the alloyed coating decreases as the temperature increases, but the reduction degree is lower than the Ti-6Al-4V alloy. The specific wear ratio is higher than that of the Ti-6Al-4V alloy, indicating that the wear resistance ability of alloying coating is relatively poor under high temperature. 
Table 6. The wear width, depth, volume, and specific wear rate of Ti-6Al-4V alloy at different temperature.

\begin{tabular}{ccccc}
\hline Temperature $\left({ }^{\circ} \mathbf{C}\right)$ & Wear Width b $\mathbf{( m m )}$ & Wear Depth h $\mathbf{( m m )}$ & Wear Volume $V_{W}\left(\mathbf{m m}^{\mathbf{3}}\right)$ & $\begin{array}{c}\text { Specific Wear Rate } \\
\left(\mathbf{m m}^{3} \cdot \mathbf{N}^{-1} \cdot \mathbf{m}^{-1}\right)\end{array}$ \\
\hline 25 & 1.100 & $23.169 \times 10^{-3}$ & 0.2549 & $0.089 \times 10^{-3}$ \\
350 & 0.644 & $19.385 \times 10^{-3}$ & 0.1248 & $0.043 \times 10^{-3}$ \\
700 & 0.278 & $15.743 \times 10^{-3}$ & 0.0438 & $0.015 \times 10^{-3}$ \\
\hline
\end{tabular}

Table 7. The wear width, depth, volume, and specific wear rate of alloying coating under different temperature.

\begin{tabular}{ccccc}
\hline Temperature $\left({ }^{\circ} \mathbf{C}\right)$ & Wear Width b $\mathbf{( m m )}$ & Wear Depth h $\mathbf{( m m )}$ & Wear Volume $V_{W}\left(\mathbf{m m}^{\mathbf{3}}\right)$ & $\begin{array}{c}\text { Specific Wear Rate } \\
\left(\mathbf{m m}^{3} \cdot \mathbf{N}^{-1} \cdot \mathbf{m}^{-1}\right)\end{array}$ \\
\hline 25 & 0.878 & $15.961 \times 10^{-3}$ & 0.1401 & $0.049 \times 10^{-3}$ \\
350 & 0.789 & $14.43 \times 10^{-3}$ & 0.1259 & $0.044 \times 10^{-3}$ \\
700 & 0.622 & $11.292 \times 10^{-3}$ & 0.0702 & $0.024 \times 10^{-3}$ \\
\hline
\end{tabular}

\subsubsection{Effect on Wear Morphology}

Figure 13 shows the wear morphology of Ti-6Al-4V alloy at different temperatures. As shown in Figure 13, with increased temperature, the wear width gradually narrowed and the wear depth was shallow. At room temperature, the wear width was large and there was a clear and dense furrow, as shown in Figure 13a,b. As shown in Figure 13c,d, when the temperature was $350^{\circ} \mathrm{C}$, the furrow width increased, the number of furrows decreased, and the amount of debris was reduced. When the temperature increased to $700{ }^{\circ} \mathrm{C}$, the wear surface of the furrow was not obvious, the wear width reduced to $0.278 \mathrm{~mm}$, and the phenomenon of peeling appeared in the middle of the wear surface, as shown in Figure 13e,f.

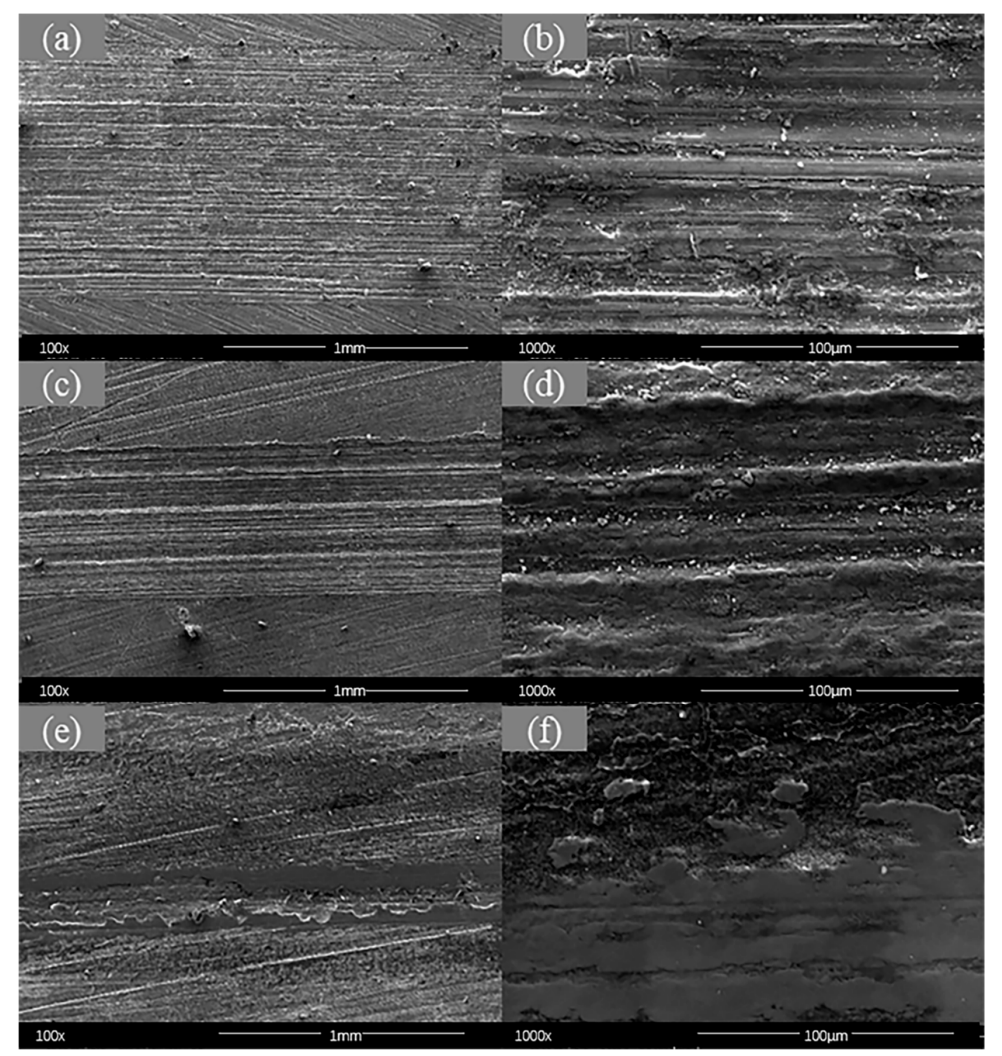

Figure 13. Wear morphology of Ti-6Al-4V alloy at different temperature. $(\mathbf{a}, \mathbf{b}): 25^{\circ} \mathrm{C} ;(\mathbf{c}, \mathbf{d}): 350{ }^{\circ} \mathrm{C}$; $(\mathbf{e}, \mathbf{f}): 700{ }^{\circ} \mathrm{C}$. 
According to the wear cross-section trajectory curve of Ti-6Al-4V alloy at different temperatures, the wear depth and width are decreased with the increase of temperature. As the temperature increases, the surface material softens and the friction resistance decreases. At the same time, the peeled oxide layer is stuck on the grinding surface during the friction and wear reciprocation process, and enters the groove or furrow of the wear scar and adheres to the surface of the titanium alloy, acting as a lubricant to reduce the wear of Ti-6Al-4V.

Figure 14 shows the wear-cross section trajectory curve of Ti-6Al-4V alloy at different temperatures. The width and depth of wear marks at room temperature are the maximum values at three different temperatures. Figure 15(a), (b) shows that there is a significant furrow and a small amount of debris on the wear surface of the alloyed coating at room temperature. When the temperature rises to $350{ }^{\circ} \mathrm{C}$, as shown in Figure $15 \mathrm{c}, \mathrm{d}$, there is a significant adhesion mark on the wear surface, and the amount of debris increases. As the temperature rises to $700{ }^{\circ} \mathrm{C}$, the wear width is narrowed, and it is difficult to observe furrow and the adhesion traces of metal. However, serious brittle flaking are found on the wear surface, as shown in Figure 15e,f.

At room temperature, the $\mathrm{Si}_{3} \mathrm{~N}_{4}$ ceramic ball is in contact with the hard phase of the coating surface to produce a normal stress and shear stress. At the same time, under the action of normal stress, the abrasive debris slides on the contact surface and rubs the groove marks. As the temperature increases, the surface metal material softens, the hardness decreases, and the plastic deformation is serious, causing the dislocation slip rate to be less than the plastic deformation rate, and the material continuity is destroyed to form micro-cracks. Micro-cracks continue to spread to the surface of the material to form macro-cracks, and break away from the surface of the material. The wear goes back and forth continuously, and the metal detached from the surface of the material is pressed against the surface of the material again under normal stress. When the temperature rises to $700{ }^{\circ} \mathrm{C}$, the surface will be severely oxidized, and the resulting oxide film will be detached from the metal surface under the action of normal stress and shear force, causing peeling. Because the oxide layer is thin, the lubrication effect of the oxide film is relatively small, wear continues, not only resulting in poorer wear resistance than Ti6Al4V alloy.

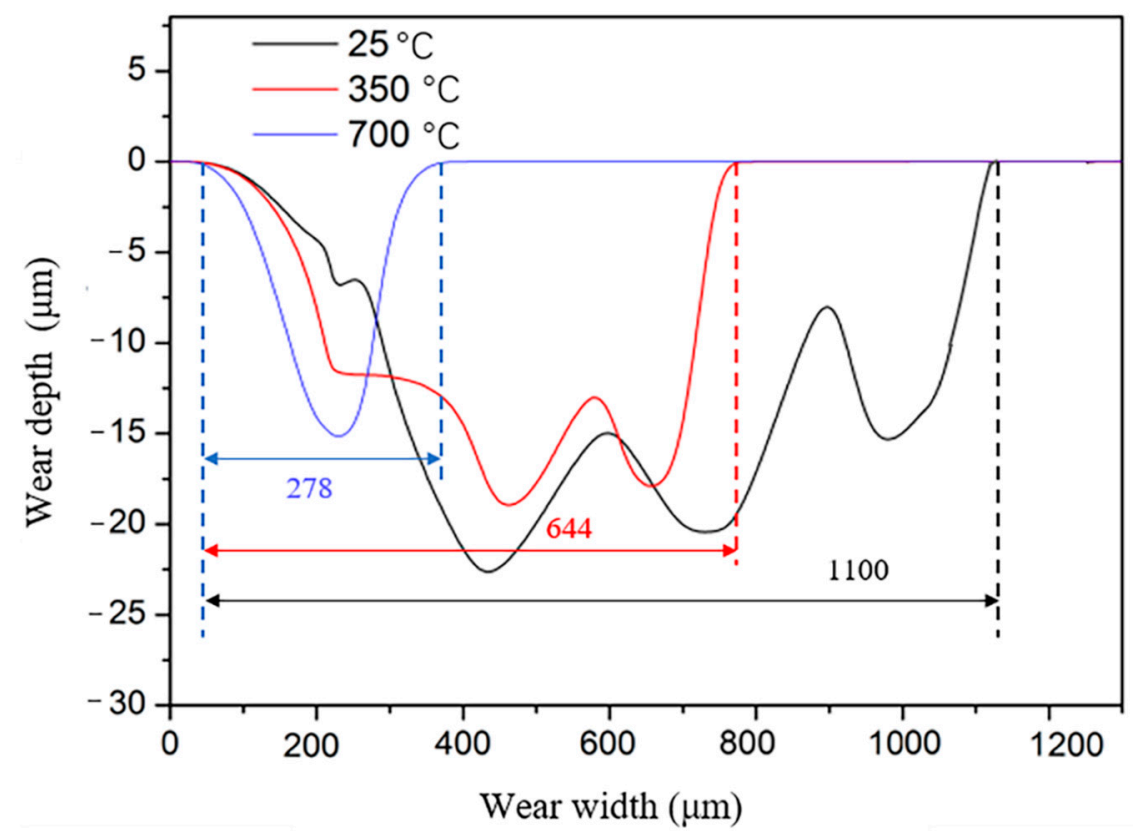

Figure 14. The wear cross-section trajectory curve of Ti-6Al-4V alloy at different temperatures. 


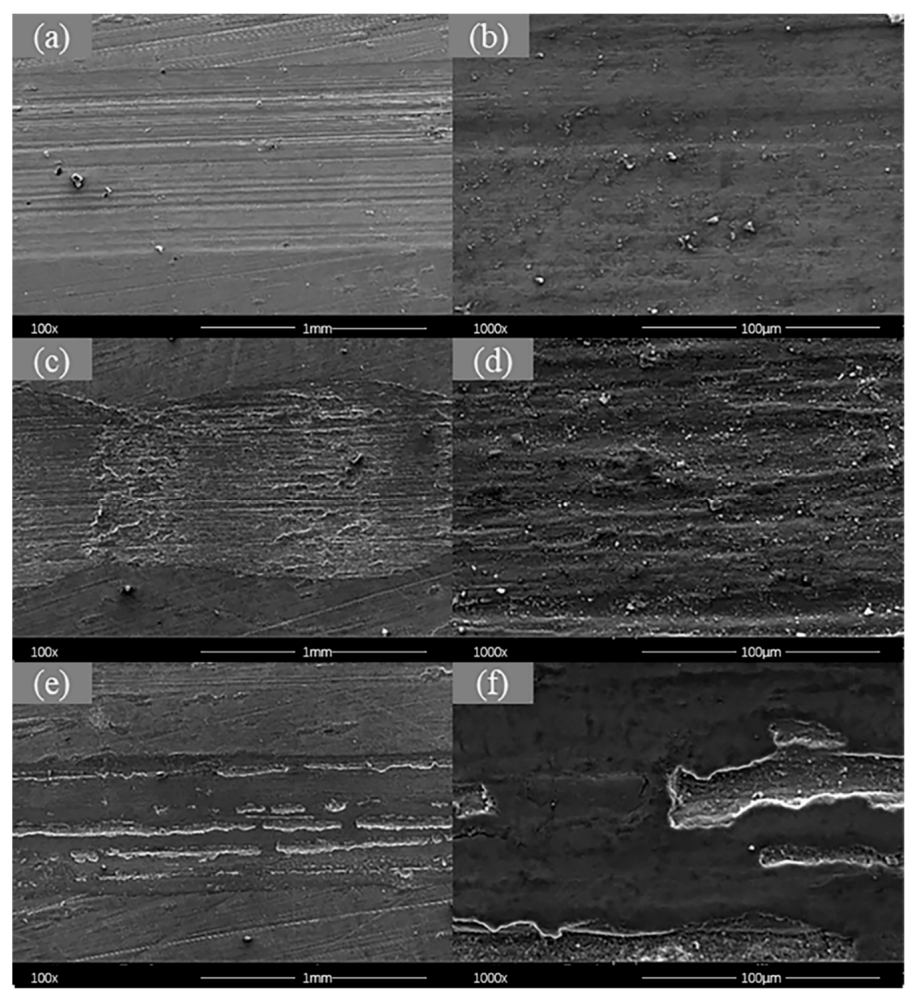

Figure 15. Wear morphology of alloying coating at different temperature: $(\mathbf{a}, \mathbf{b}): 25^{\circ} \mathrm{C}$; (c,d): $350{ }^{\circ} \mathrm{C}$; $(\mathbf{e}, \mathbf{f}): 700{ }^{\circ} \mathrm{C}$.

It can be seen from Figure 16 that, with the increase of temperature, the wear width and depth of the alloyed coating decreases, and the wear rate decreases. At room temperature, the wear width and depth of alloying coating are smaller than that of Ti-6Al-4V alloy. The reason may be that the surface hardness of the coating is higher than that of Ti-6Al-4V alloy at room temperature, which can reduce the friction extrusion of $\mathrm{Si}_{3} \mathrm{~N}_{4}$ ceramic ball on the surface and reduce the cutting resistance of grinding ball on titanium alloy. However, at $350{ }^{\circ} \mathrm{C}$, the wear width of the alloyed coating is larger than that of Ti-6Al-4V alloy, and the wear depth is smaller than that of Ti-6Al-4V alloy. The wear volume and specific wear rate of the two alloys are similar. At $700{ }^{\circ} \mathrm{C}$, the wear width of the alloyed coating is larger than that of the Ti-6Al-4V alloy, and the wear depth is smaller than that of the Ti-6Al-4V alloy. The results show that the wear resistance of the alloyed coating is not ideal at high temperatures.

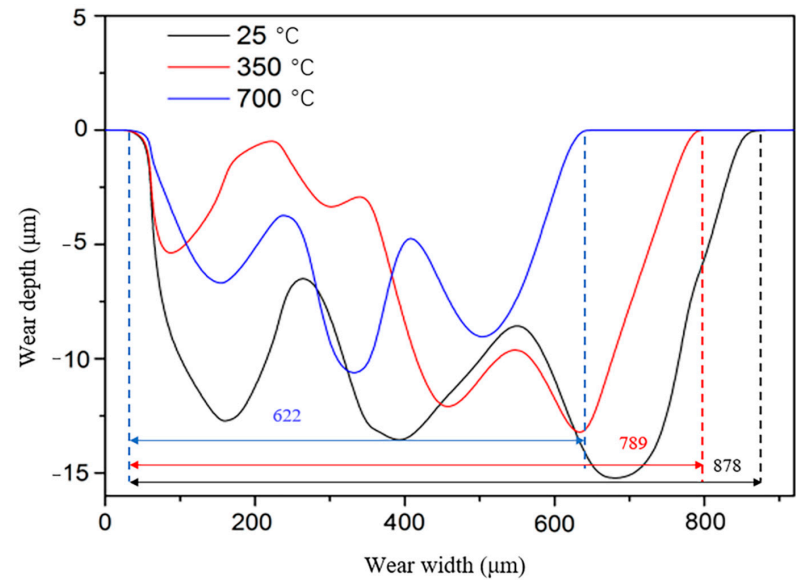

Figure 16. The wear cross-section trajectory curve of alloying coating at different temperatures. 


\section{Conclusions}

In this paper, the wear properties of Ti-6Al-4V alloy and composite coating composed of $\mathrm{Ni60 \textrm {A }}$, TiN, $\mathrm{Al}$, and $\mathrm{Si}$, were investigated by studying the friction coefficient, abrasion loss, wear morphology, wear volume, and specific wear rate. Conclusions are as follows:

(1) At room temperature $\left(25^{\circ} \mathrm{C}\right)$, with the increase of load $(3 \mathrm{~N}, 6 \mathrm{~N}, 9 \mathrm{~N})$, the wear width and depth of Ti-6Al-4V alloy increase, and the friction coefficient decreases from $0.47 \sim 0.53$ to $0.39 \sim 0.44$, The results show that the wear resistance of the alloyed coating is better than that of Ti-6Al-4V Alloy at room temperature.

(2) With the increase of temperature $\left(25^{\circ} \mathrm{C}, 350^{\circ} \mathrm{C}, 700{ }^{\circ} \mathrm{C}\right)$, the wear width and depth of Ti-6Al-4V alloy and alloying coating decrease. The friction coefficient of Ti-6Al-4V alloy decreases from $0.41 \sim 0.46$ to $0.36 \sim 0.40$. The friction coefficient of alloying coating becomes unstable with the increase of temperature. The wear rate of alloying coating is lower than that of Ti-6Al-4V alloy at $25^{\circ} \mathrm{C}$. At $350{ }^{\circ} \mathrm{C}$, the wear rate of the alloy coating is similar to that of Ti-6Al-4V alloy, but at $700{ }^{\circ} \mathrm{C}$, the wear rate is higher than that of Ti-6Al-4V alloy. The reason is that with the increase of temperature, the surface alloy material softens, the hardness decreases, the surface oxidation occurs seriously, and the oxide film breaks away from the metal surface under the action of normal stress and shear stress, resulting in the insufficient wear resistance of the alloying coating.

(3) Under the high temperature condition, the wear extent, wear volume, and specific wear rate of the alloying coating are lower than the room temperature, but the wear resistance is not satisfactory compared with the Ti-6Al-4V alloy under high temperature condition, indicating that the alloying coating, with good oxidation resistance under high temperature conditions, failed to get better wear resistance.

Author Contributions: Conceptualization, A.H.; methodology, A.H.; validation, Q.C.; formal analysis, Q.C. and J.Z.; investigation Q.C. and P.W.; writing-original draft preparation, Q.C. and J.Z.; writing-review and editing, Q.C. All authors have read and agreed to the published version of the manuscript.

Funding: This research was financially supported by the Key R\&D Projects (National Key projects) (No. 2017YFE0100100).

Institutional Review Board Statement: Ethical review and approval were waived for this study, due to "Not applicable" for studies not involving humans or animals.

Informed Consent Statement: Not applicable.

Data Availability Statement: Did not report any data.

Acknowledgments: The authors gratefully acknowledge the State Key Laboratory of Material Processing and Die \& Mould Technology for their technical and equipment support.

Conflicts of Interest: The authors declare no conflict of interest.

\section{References}

1. Chonghe, L.; Ming, Z.; Ning, W.; Xionggang, L.; Shentao, C. Application of titanium alloy in airplane. Chin. J. Rare Met. 2009, 33, 84-91. [CrossRef]

2. Weng, F.; Chen, C.; Yu, H. Research status of laser cladding on titanium and its alloys: A review. Mater. Des. 2014, 58, 412-425. [CrossRef]

3. Squillace, A.; Prisco, U.; Ciliberto, S.; Astarita, A. Effect of welding parameters on morphology and mechanical properties of Ti-6Al-4V laser beam welded butt joints. J. Mater. Process. Technol. 2012, 212, 427-436. [CrossRef]

4. Fang, Y.; Jiang, X.; Song, T.; Mo, D.; Luo, Z. Pulsed laser welding of Ti-6Al-4V titanium alloy to AISI 316L stainless steel using $\mathrm{Cu} / \mathrm{Nb}$ bilayer. Mater. Lett. 2019, 244, 163-166. [CrossRef]

5. Liu, X.-B.; Meng, X.-J.; Liu, H.-Q.; Shi, G.-L.; Wu, S.-H.; Sun, C.-F.; Wang, M.-D.; Qi, L.-H. Development and characterization of laser clad high temperature self-lubricating wear resistant composite coatings on Ti-6Al-4V alloy. Mater. Des. 2014, 55, 404-409. [CrossRef]

6. Liu, Q.-M.; Zhang, Z.-H.; Liu, S.-F.; Yang, H.-Y. Application and development of titanium alloy in aerospace and military hardware. J. Iron Steel Res. 2015, 29, 4-10. [CrossRef] 
7. Fu, Y.; Song, Y.; Hui, S. Research and application of typical aerospace titanium alloys. Chin. J. Rare Met. 2006, 30, 850-856. [CrossRef]

8. Bansal, D.G.; Eryilmaz, O.; Blau, P.J. Surface engineering to improve the durability and lubricity of Ti-6Al-4V alloy. Wear 2011, 271, 2006-2015. [CrossRef]

9. Straffelini, G.; Molinari, A. Dry sliding wear of Ti-6Al-4V alloy as influenced by the counterface and sliding conditions. Wear 1999, 236, 328-338. [CrossRef]

10. Ma, A.; Liu, D.; Tang, C.; Zhang, X.; Liu, C. Influence of glow plasma Co-based alloying layer on sliding wear and fretting wear resistance of titanium alloy. Tribol. Int. 2018, 125, 85-94. [CrossRef]

11. Dai, J.; Li, S.; Zhang, H.; Yu, H.; Chen, C.; Li, Y. Microstructure and high-temperature oxidation resistance of Ti-Al-Nb coatings on a Ti-6Al-4V alloy fabricated by laser surface alloying. Surf. Coat. Technol. 2018, 344, 479-488. [CrossRef]

12. Yu, W.; Tian, J.; Tian, W.; Zhao, J.; Li, Y.; Liu, Y. Study of yttrium and cerium on the oxidation resistance of silicide coatings prepared on Ti-6Al-4V alloy by pack-cementation process. J. Rare Earths 2015, 33, 221-226. [CrossRef]

13. Nair, A.M.; Muvvala, G.; Nath, A.K.; Gopinath, M. A study on in-situ synthesis of TiCN metal matrix composite coating on Ti-6Al-4V by laser surface alloying process. J. Alloys Compd. 2019, 810, 151901. [CrossRef]

14. Tian, Y.; Chen, C.; Wang, D.; Huo, Q.; Lei, T. Laser surface alloying of pure titanium with TiN-B-Si-Ni mixed powders. Appl. Surf. Sci. 2005, 250, 223-227. [CrossRef]

15. Weng, F.; Yu, H.; Liu, J.; Chen, C.; Dai, J.; Zhao, Z. Microstructure and wear property of the Ti5Si3/TiC reinforced Co-based coatings fabricated by laser cladding on Ti-6Al-4V. Opt. Laser Technol. 2017, 92, 156-162. [CrossRef]

16. Tian, Y.S.; Chen, L.X.; Chen, C.Z. Microstructures of composite coatings fabricated on Ti-6Al-4V by laser alloying technique. Cryst. Growth Des. 2006, 6, 1509-1513. [CrossRef]

17. Liu, H.; Zhang, X.; Jiang, Y.; Zhou, R. Microstructure and high temperature oxidation resistance of in-situ synthesized TiN/Ti3Al intermetallic composite coatings on Ti6Al4V alloy by laser cladding process. J. Alloy. Compd. 2016, 670, 268-274. [CrossRef]

18. Zeng, X.; Yamaguchi, T.; Nishio, K. Characteristics of Ti (C, N)/TiB composite layer on Ti-6Al-4V alloy produced by laser surface melting. Opt. Laser Technol. 2016, 80, 84-91. [CrossRef]

19. Gopinath, M.; Thota, P.; Nath, A.K. Role of molten pool thermo cycle in laser surface alloying of AISI 1020 steel with in-situ synthesized TiN. Surf. Coat. Technol. 2019, 362, 150-166. [CrossRef]

20. Guo, Y.; Li, C.; Zeng, M.; Wang, J.; Deng, P.; Wang, Y. In-situ TiC reinforced CoCrCuFeNiSi0. 2 high-entropy alloy coatings designed for enhanced wear performance by laser cladding. Mater. Chem. Phys. 2020, 242, 122522. [CrossRef]

21. Liang, J.; Liu, X.-B.; Ke, J.; Luo, Y.-S.; Liang, L. Preparation and high temperature oxidation resistance of laser deposited Ti5Si3/MoSi2/Mo5Si3 reinforced $\alpha$-Ti/NiTi composite coatings. Surf. Coat. Technol. 2019, 372, 56-64. [CrossRef]

22. Song, J.; Han, Y.; Fang, M.; Hu, F.; Ke, L.; Li, Y.; Lei, L.; Lu, W. Temperature sensitivity of mechanical properties and microstructure during moderate temperature deformation of selective laser melted Ti-6Al-4V alloy. Mater. Charact. 2020, 110342. [CrossRef]

23. Chen, C.; Feng, X.; Shen, Y. Oxidation behavior of a high Si content Al-Si composite coating fabricated on Ti-6Al-4V substrate by mechanical alloying method. J. Alloys Compd. 2017, 701, 27-36. [CrossRef]

24. Zha, M.; Wang, H.Y.; Lü, S.J.; Zhang, N.; Li, D.; Jiang, Q.C. Self-propagating High-temperature Synthesis of Ti5Si3/TiAl3 Intermetallics. ISIJ Int. 2009, 49, 453-457. [CrossRef]

25. Zhang, Y.Z.; Gao, S.Y.; Shi, L.K. Microstructure and properties of laser clad Ni60A+WC/12Co composite coating. Heat Treat. Met. 2002, 27, 10-13. [CrossRef]

26. Peng, X.; Guo, H.; Wang, T.; Yao, Z. Effects of $\beta$ treatments on microstructures and mechanical properties of TC4-DT titanium alloy. Mater. Sci. Eng. A 2012, 533, 55-63. [CrossRef]

27. Gee, M.; Gant, A.; Hutchings, I.; Kusano, Y.; Schiffman, K.; Van Acker, K.; Poulat, S.; Gachon, Y.; Von Stebut, J.; Hatto, P.; et al. Results from an interlaboratory exercise to validate the micro-scale abrasion test. Wear 2005, 259, 27-35. [CrossRef] 